\title{
IDŐJÁRÁS
}

Quarterly Journal of the Hungarian Meteorological Service

Vol. 123, No. 1, January - March, 2019, pp. 39-55

\section{Dust deposition, microscale flow- and dispersion model of particulate matter, examples from the city center of Budapest}

\author{
Orsolya Farkas and Ákos Török* \\ Budapest University of Technology and Economics, \\ Department of Engineering Geology and Geotechnics \\ Müegyetem rakpart 3, 1111 Budapest, Hungary \\ *Corresponding authorE-mail: torokakos@mail.bme.hu \\ (Manuscript received in final form June 14, 2018)
}

\begin{abstract}
Despite the air quality improvement, air pollution is still a severe problem in Budapest, and the city is one of the most polluted capitals of Europe. Dust has an adverse health effect, and it also causes aesthetic changes to buildings. Dust contributes to the damage of stone and may also result material loss. The paper analyzes the composition of dust and also describe its flow patterns in the city center of Budapest. The study area is located in one of the most polluted areas of Budapest, at Margit Boulevard. Dust samples were collected from the facades of buildings. Samples were analyzed with particle size analysis with laser diffraction, point counting of particles by optical microscopy, and X-Ray Diffraction (XRD). To simulate the airflow and the dispersion of particulate matter $\left(\mathrm{PM}_{10}\right)$, a computational fluid dynamics code called MISKAM (Mikroskaliges Strömung- und Ausbreitungsmodell - microscale flow and dispersion model for built up areas) was used. The results suggest that dust deposition is controlled by the flow pattern. Analyzed dust samples contain wind driven mineral grains (quartz, dolomite) and also human activity related pollutants such as fly ash and soot.
\end{abstract}

Key-words: dust, air pollution, mineralogy, MISKAM, historical buildings

\section{Introduction}

The high concentration of dust (particulate matter) has an adverse effect on human health and also causes alterations in structures and monuments (Brimblecombe and Grossi, 2009). Natural sources of airborne dust may include soil erosion, volcanic activity, forest fires, etc. (Querol et al., 2004; Gieré and 
Querol, 2010). The main anthropogenic sources of dust are from burning coal, oil, wood (Pósfai and Buseck, 2010), and waste, furthermore the road traffic emissions also have significant contribution to dust (Grobéty et al., 2010; Salma et al., 2017). In addition, the already deposited dust can be remobilized, stirred, and after redeposited again (Salma et al., 2004a).

The health risks of particulate matter and the relationship between the fine particulate pollutants in the air and mortality have been studied in details in the past decades (Reichardt, 1995; Lippman et al., 2000; Samet et al., 2000; Wichmann et al., 2000; Pope et al., 2002). There is a linear correlation between concentrations of particulate pollutants and the number of diseases (Dockery et al., 1993).

Diesel-engine vehicles have a more significant contribution to the airborne dust emissions than petrol fueled ones. The harmful effects of emissions of diesel-powered engines have been studied by applying $\mathrm{C}$ isotopic analysis (Hildemann et al., 1994).

The particulates cause a visual damage on the buildings. Besides their optical effect, particulates contribute to the black crust formation and damage of building stones. Dust attracts sulphur dioxide and has a catalytic role in the formation of gypsum crystals (Rodriguez-Navarro and Sebastian, 1996) that damage buildings during their crystallization. The atmospheric sulphur concentration and deposition in Hungary have reduced in the past years, and previous simulations (Bozó, 1998; Havasi et al., 2001) clearly demonstrated their pathways and deposition.

Previous studies have demonstrated that from polymorph varieties of $\mathrm{SiO}_{2}$, the tridimite and crystobalite are more harmful when inhaled than the quartz. The amorphous $\mathrm{SiO}_{2}$ varieties seem to have limited health effects (Heaney and Banfield, 1993).

The composition of settling dust was studied in Transsylvania (Farkas and Weiszburg, 2006). In this study, samples collected from 18 sites were compared. The results clearly reflected the influence of different industrial activities, however, the transportation related contribution to dust was not related.

Most of the comprehensive studies are focusing on air quality and urban climate in European capital cities (Borbély-Kiss et al., 1999; Kukkonen, 2003; Borsós et al., 2012; Probáld, 2014; Ferenczi and Bozó, 2017; Leelössy et al., 2017).

In the current paper, the terminology of Gieré and Querol (2010) was used. Particulate matter includes all particles with all size-ranges; fine particles less than $2.5 \mu \mathrm{m}$ in diameter $\left(\mathrm{PM}_{2.5}\right)$ and coarse particles larger than $2.5 \mu \mathrm{m}$ in diameter (including particles larger than $\mathrm{PM}_{10}$ ). Dust term includes very fine to very coarse particles (up to a few $\mathrm{mm}$ in diameter), without indicating its source. Hence, settling dust has a size-range of nanometre to a few $\mathrm{mm}$, but the lowest particle size analyzed in this paper was $0.02 \mu \mathrm{m}$. 
In this paper we follow the above listed findings. To describe air pollution, two main tools were applied to assess the dust in the city centre. Dust samples were collected and analyzed to understand their composition and judge the contribution of anthropogenic sources. Besides sample collection, the $\mathrm{PM}_{10}$ deposition was also modeled by using a computational fluid dynamics (CFD) software to describe the sites, where highest amount of particulate matter is expected to accumulate. The combination of these two approaches allowed demonstrating the interaction between particulate matter deposition and flow patterns.

\section{Materials and methods}

\subsection{Sampling sites}

The study area is located in Hungary, in the second district of Budapest, at Margit Boulevard (Fig. 1). It is a very busy, often traffic congested boulevard with high air pollution levels.

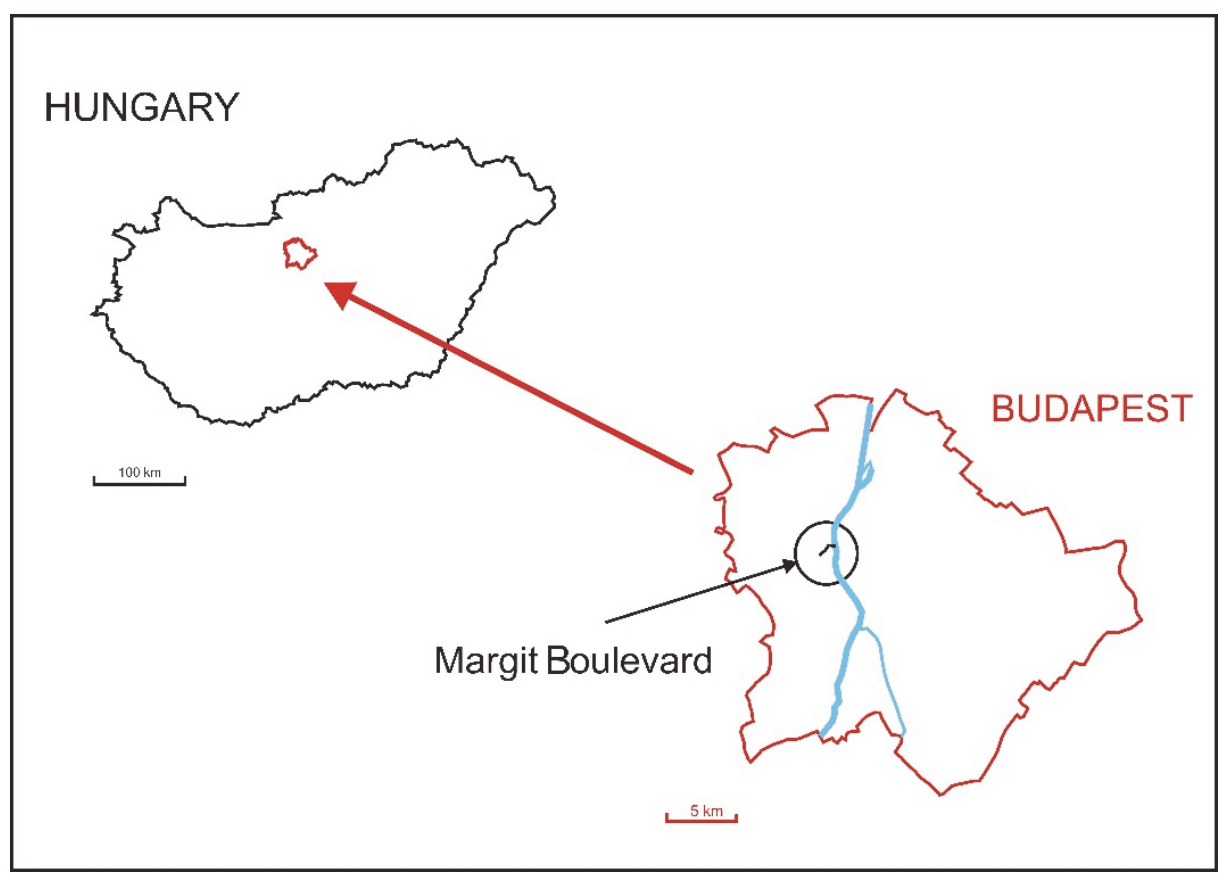

Fig. 1. Location of study area in Hungary and in Budapest

Seven dust samples were collected from the main boulevard and from the adjoining smaller streets. The sampling points and selected buildings are shown in Fig. 2. The description of sampling localities, the host rock of the samples, and sample codes are given in Table 1. Four samples are from the facades of three monuments (Semmelweis Medical Historical Library, Bauhaus style building in Margit Boulevard 15-17., and Margit-house), while the rest of the samples are coming from non-protected buildings. 


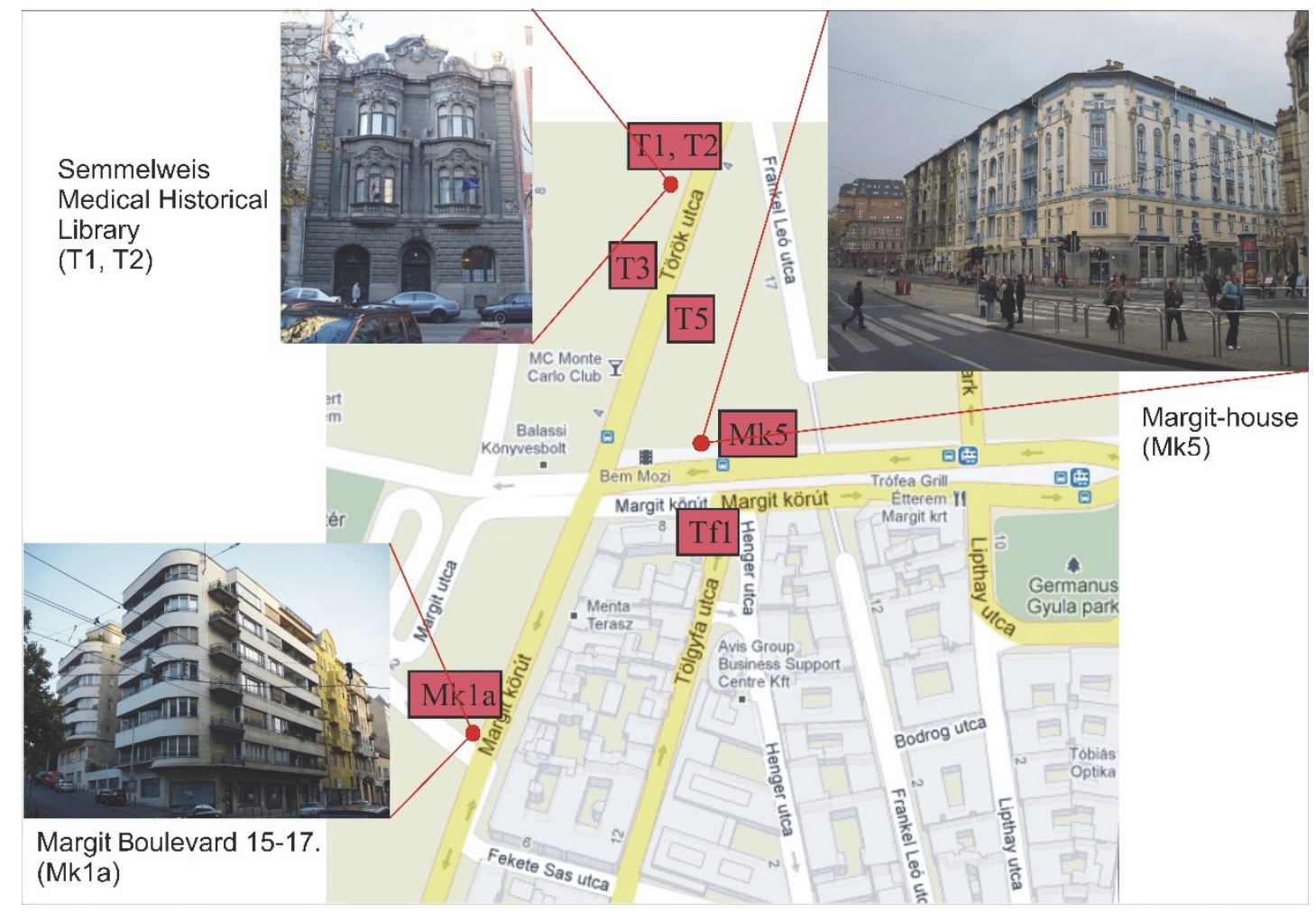

Fig. 2. Sampling points in the city center of Budapest (see detailed description of sampling sites in Table 1).

Table 1. Sample codes, description of sample localities and host rock

\begin{tabular}{|c|c|c|c|c|}
\hline Sample & Locality & $\begin{array}{c}\text { Elevation } \\
\text { above ground } \\
\text { level }[\mathbf{m}] \\
\end{array}$ & Host rock & $\begin{array}{l}\text { Description of the } \\
\text { sampling site }\end{array}$ \\
\hline $\mathrm{T} 1$ & $\begin{array}{l}\text { Budapest, Török Street } 12 . \\
\text { (Semmelweis Medical } \\
\text { Historical Library) }\end{array}$ & 1.3 & Breccia & Window ledge \\
\hline $\mathrm{T} 2$ & $\begin{array}{l}\text { Budapest, Török Street } 12 . \\
\text { (Semmelweis Medical } \\
\text { Historical Library) }\end{array}$ & 2.0 & Breccia & $\begin{array}{l}\text { Small cavities of } \\
\text { ashlars }\end{array}$ \\
\hline $\mathrm{T} 3$ & Budapest, Török Street 6 . & 1.1 & $\begin{array}{l}\text { Tardos } \\
\text { limestone }\end{array}$ & Top of footing \\
\hline T5 & Budapest, Török Street 1-3. & 0.6 & $\begin{array}{l}\text { Tardos } \\
\text { limestone }\end{array}$ & Window ledge \\
\hline MK1a & $\begin{array}{l}\text { Budapest, Margit Boulevard } \\
15-17 .\end{array}$ & 0.8 & Travertine & Window ledge \\
\hline MK5 & $\begin{array}{l}\text { Budapest, Margit Boulevard } \\
\text { 5/A. } \\
\text { (Margit-house) }\end{array}$ & 1.0 & Travertine & Window ledge \\
\hline TF1 & Budapest, Tölgyfa Street 30. & 0,5 & Travertine & $\begin{array}{l}\text { Ledge inlet and } \\
\text { ledge corner }\end{array}$ \\
\hline
\end{tabular}




\subsection{Analytical methods}

The dust samples were analyzed by using three techniques: (i) point counting of particles by optical microscopy (ii) X-Ray diffraction (XRD), and (iii) particle size analysis by laser diffraction (Table 2).

Table 2. Analytical techniques and samples

\begin{tabular}{lccc}
\hline \hline Sample & $\begin{array}{c}\text { Point counting of } \\
\text { particles by optical } \\
\text { microscopy }\end{array}$ & X-Ray Diffraction & $\begin{array}{c}\text { Particle size } \\
\text { analysis with } \\
\text { laser diffraction }\end{array}$ \\
\hline \hline T1 & $\checkmark$ & & \\
T2 & $\checkmark$ & $\checkmark$ & $\checkmark$ \\
T3 & $\checkmark$ & $\checkmark$ & $\checkmark$ \\
T5 & $\checkmark$ & $\checkmark$ & $\checkmark$ \\
Mk1a & $\checkmark$ & & $\checkmark$ \\
Mk5 & $\checkmark$ & $\checkmark$ & $\checkmark$ \\
Tf1 & $\checkmark$ & & \\
\hline
\end{tabular}

The proportion of components was determined by Dino Lite Microscopy resolution of 1.3 megapixel, magnification of 10 to $200 x$.

It was possible to measure and label particles by using the software of microscope. 3 areas $1 \mathrm{~mm}^{2}$ each, were selected in the samples, where the mineralogical composition were evaluated based on particle counting. The results are presented as mean values of three counting.

The mineralogical composition was determined by X-Ray diffraction (XRD) with a Phillips Diffractometer (PW 1800, Cu-anode, $45 \mathrm{kV}, 30 \mathrm{~mA}$, Göttingen, Germany). Powder X-Ray patterns were obtained using PANalytical $X^{\prime}$ Pert HighScore Plus software. The diffraction data were recorded from $2^{\circ}$ to $70^{\circ} 2 \Theta$ via a continuous scan with a routine scan program.

Particle size distribution was measured by laser diffraction (Jones, 2003). Low Angle Laser Light Scattering (LALLS) was used for particle sizes of 0.02 to $2000 \mu \mathrm{m}$.

Sample preparation was made by using ultrasonic sample segregation (equipment: Bandelin, energy: $0.24 \mathrm{~kJ}$, run time: $30 \mathrm{sec}$ ). The analysis took 90 sec with Beckman Coulter, LS 13320. 


\subsection{Flow- and dispersion model MISKAM}

To simulate the airflow and the dispersion of pollutant $\mathrm{PM}_{10}$, a computational fluid dynamics (CFD) model was used. This particulate range was used since $\mathrm{PM}_{10}$ emission factors were available; i.e., this is the largest particle size for which transportation related emission factors were available. The main aim of the model was to identify flow patterns and link it to concentration differences of particulate matter. The CFD simulations are generally used to identify flow patterns and to simulate pollution dispersion. In addition, the results of modeling are commonly applied in urban development planning and design. As part of environmental impact analysis, the results of the pollution dispersion pattern can be directly implemented in development plans. MISKAM (Mikroskaliges Strömung- und Ausbreitungsmodell) was developed by J. Eichhorn (University of Mainz) to simulate pollution dispersion in urban areas (Eichhorn, 2008). The model incorporates a Reynolds-averaged Navier-Stokes solver adopting the Boussinesq-approximations to eliminate sound waves with a modified $\mathrm{k}-\varepsilon$ turbulence closure (Eichhorn and Kniffka, 2010).

The study area is a busy intersection, and its surroundings $(400 \mathrm{~m} \times 400 \mathrm{~m})$ are located close to the city center of Budapest, at the intersection of Margit Boulevard and Török Street (Fig. 2).

For the input of model parameters, such as geometry, topography, MISKAM Data Processing software (developed by the Department of Fluid Mechanics, Budapest University of Technology and Economics) was used. Tecplot 360 software was used to visualize the results of simulations (wind flow, concentration distribution, etc.).

Medium-rise buildings with 4-5 floors are found in the modeled area. Additional input parameters were the ground plan and the elevation of buildings. For the meteorological characteristics, wind-statistics were created. The prevailing wind direction is from the WNW (west-northwest), while for the wind speed, a $2 \mathrm{~m} / \mathrm{s}$ velocity was used at an elevation of $10 \mathrm{~m}$. For this wind speed the software generated a logarithmic wind profile.

A $1 \mathrm{~cm}$ of surface roughness value was added for the ground surface, and the same value was applied for the buildings. Additional input data were: (i) leaf area density (LAD) of $0.5 \mathrm{~m}^{2} / \mathrm{m}^{3}$ and (ii) vegetation coverage (b) of $1 \mathrm{~m}^{2} / \mathrm{m}^{2}$. The pollution concentration of inflowing air to the model area was $0 \mathrm{~kg} / \mathrm{m}^{3}$, but when pollution concentration of the study area was calculated, the background concentration of $\mathrm{PM}_{10}$ was added, which was taken from the dataset of a nearby air quality monitoring station (Széna Square, Budapest I. district).

The traffic load of the roads was defined by traffic count by the authors. The traffic count was performed at one intersection (Margit Boulevard, Török Street and Margit Street) from 4 directions in 3 time periods (peak hours: morning, afternoon, peak-off hours: evening). Estimated traffic volumes were assigned to the surrounding streets. $\mathrm{PM}_{10}$ emissions were calculated by using 
HBEFA (Handbook Emission Factors for Road Transport) and KTI (Institute for Transport Sciences Non-Profit Ltd.) databases, taking into account the various emission factors of vehicles (Infras, 2004).

\section{Results and discussion}

For each sample, the two most important components are quartz and soot. The amount of these components depends on the location and geometry of the sampling site (height, footing, or ledge, Table 1). The sample analyses suggest, that the higher proportion of soot is observed in the samples taken from Török Street (T2, T3, T5), where there is a wind-protected area. It is a narrower street, the soot particles can settle down, and the wind does not take the fine grains. The higher ratio of quartz $(\mathrm{Mk} 1 \mathrm{a}, \mathrm{Mk} 5, \mathrm{TF} 1)$ is more likely to be linked to Margit Boulevard (Table 3). Here, the volume of traffic and disturbed dust are higher and probably the wind is stronger, thus it is easier to grab particles of small fraction (fly ash, soot).

Table 3. Point counting results (percentage) of particles by optical microscopy

\begin{tabular}{lccccc}
\hline \hline & $\begin{array}{c}\text { Quartz } \\
{[\%]}\end{array}$ & $\begin{array}{c}\text { Fly ash } \\
{[\%]}\end{array}$ & $\begin{array}{c}\text { Soot } \\
{[\%]}\end{array}$ & $\begin{array}{c}\text { Carbonated } \\
\text { parts } \\
{[\%]}\end{array}$ & $\begin{array}{c}\text { Other } \\
{[\%]}\end{array}$ \\
\hline \hline Mk1a & 64 & 10 & 15 & 6 & 5 \\
Mk5 & 55 & 8 & 15 & 4 & 18 \\
T2 & 49 & 5 & 40 & 2 & 4 \\
T3 & 36 & 4 & 48 & 3 & 9 \\
T5 & 43 & 6 & 37 & 4 & 10 \\
TF1 & 57 & 7 & 21 & 2 & 13 \\
T1 & 50 & 6 & 26 & 4 & 14 \\
\hline
\end{tabular}

The results of the X-ray diffraction analysis are very similar, but some differences exist between the samples. The proportion of compounds is slightly different (Table 4). Our findings are in good agreement with the previous studies (McAlister et al., 2006) that quartz particles are commonly found in the dust of Budapest. The peaks identified on XRD diffractograms (Fig. 3) clearly confirm the prevalence of quartz in the studied samples. 
Table 4. Inorganic compounds in analyzed samples by XRD / Main mineral phases of settled dust

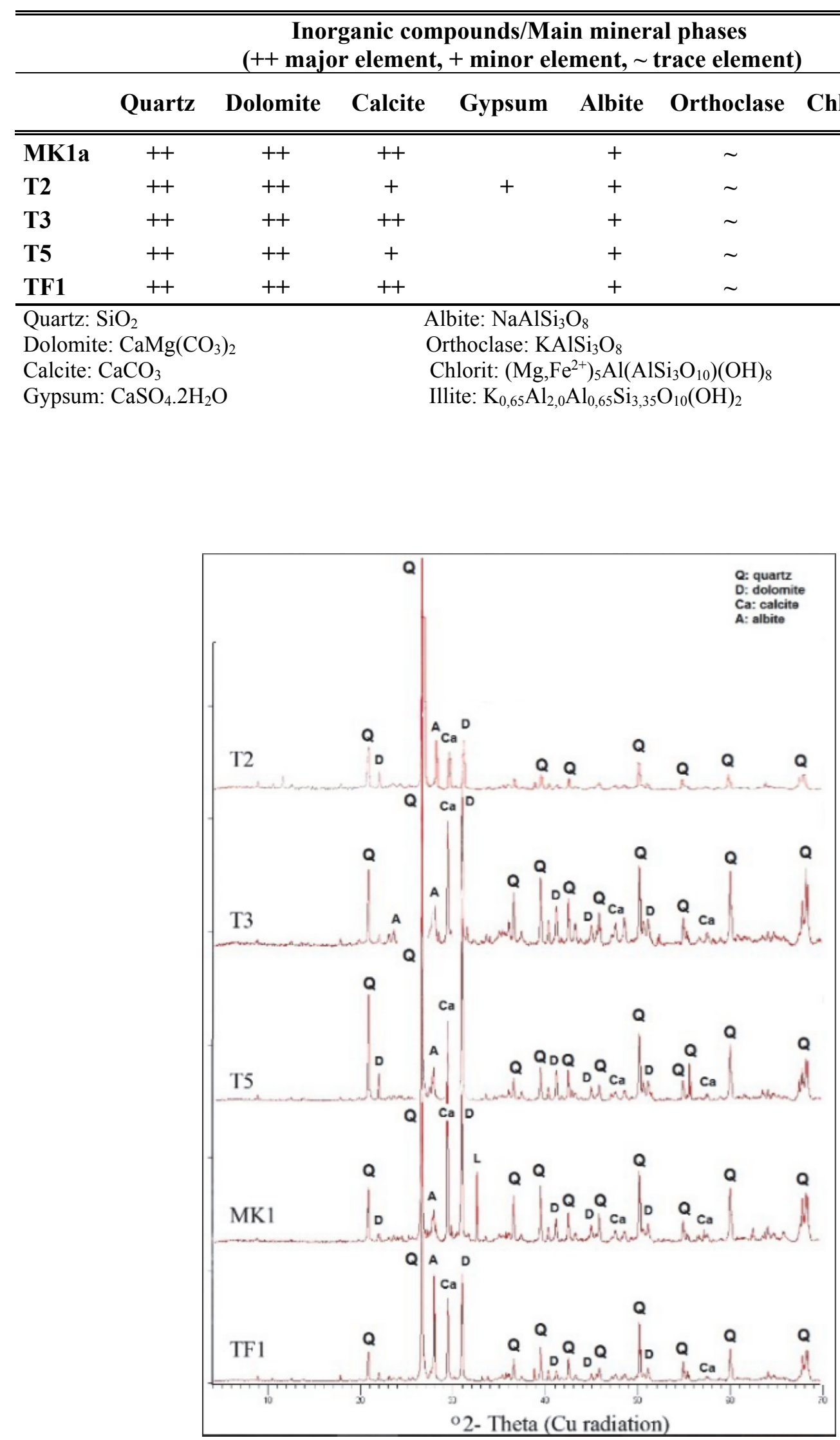

Fig. 3. X-ray diffractograms of analyzed samples. 
The settled dust contains quartz, dolomite, calcite, and albite, and a small amount of gypsum is found in sample T2. Orthoclase, chlorite, and illite are present in traces. Calcite is the main mineral of the carbonate rocks, which was used in many buildings in Budapest and was found in all collected dust samples. The quartz and feldspar content can be attributed to wind-driven mineral grains (Smith et al., 2003; Török et al., 2011; Farkas et al., 2018).

The organic compounds of dust were not analyzed, but it is known that it contains high amount of elemental and organic carbon (Salma et al., 2014b). The proportion and composition of these organic compounds changes with time, as it was documented by Salma and Maenhaut (2006). The changes are not restricted to urban areas but also indicative for rural ones (Temesi et al., 2003; Török et al., 2011).

The results of laser diffraction particle analyses are summarized in Fig. 4. Although the samples were taken from similar buildings, the size distribution of dust is markedly different. T2 and T3 dust samples were the finest. In these samples, more than $40 \%$ of particles are smaller than $20 \mu \mathrm{m}$ in diameter. The statistical analyses of particle sizes show that Mk5 and T5 contains larger particles, and $\mathrm{d}_{90}$ values of these two samples are larger than $0.2 \mathrm{~mm}$ (Table 5). It is also clear that the samples that have the largest particles have a bimodal particle size distribution (Fig. 4 and Table 6).

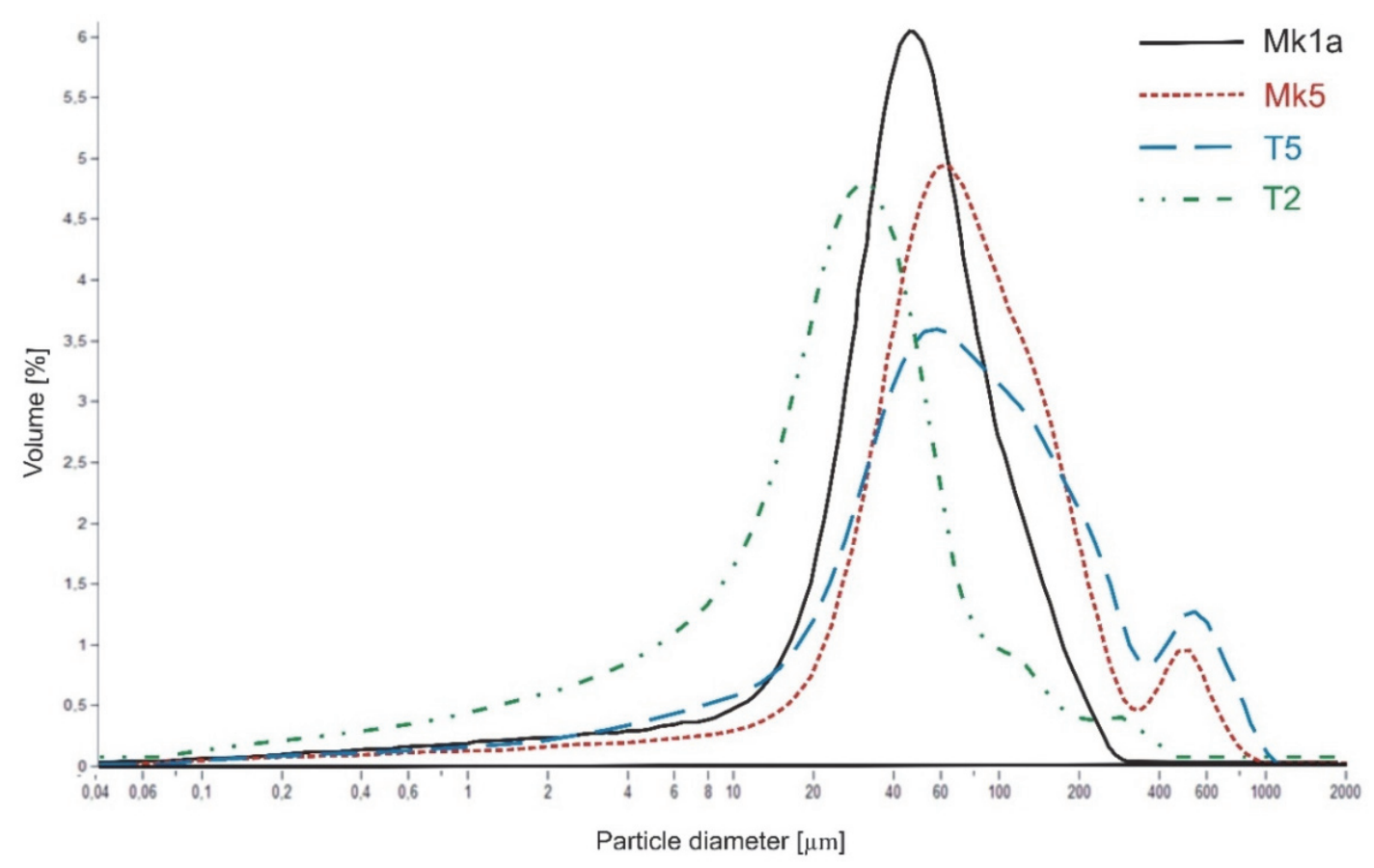

Fig. 4. Particle size distribution for four samples (Mk1a, Mk5, T5, T2) (particle diameter is shown in logarithmic scale). 
Table 5. Statistic parameters for five samples (Mk1a, Mk5, T2, T3, T5) by laser diffraction particle analysis (values are given in micrometres)

\begin{tabular}{lcccc}
\hline \hline & $\mathbf{d}_{\text {mean }}$ & $\mathbf{d}_{\mathbf{1 0}}$ & $\mathbf{d}_{\mathbf{5 0}}$ & $\mathbf{d}_{\mathbf{9 0}}$ \\
\hline \hline Mk1a & 60.1 & 13.09 & 49.97 & 119.6 \\
Mk5 & 106.9 & 21.9 & 69.95 & 210.7 \\
T2 & 34.7 & 2.795 & 23.89 & 68.3 \\
T3 & 27.22 & 2.132 & 18.22 & 61.41 \\
T5 & 113.1 & 9.137 & 60.77 & 272.8 \\
\hline
\end{tabular}

$\mathrm{d}_{\text {mean: }}$ mean value

$\mathrm{d}_{10}: 10 \%$ percentile $(10 \%$ of the data is smaller than this value)

$\mathrm{d}_{50}: 50 \%$ percentile $(50 \%$ of the data is smaller than this value, equal to the median value)

$\mathrm{d}_{90}: 90 \%$ percentile $(90 \%$ of the data is smaller than this value)

Table 6. Particle size distribution of analyzed samples (Mk1a, Mk5, T2, T3, T5), data obtained from laser diffraction particle analysis

\begin{tabular}{cccccc}
\hline \hline $\begin{array}{c}\text { Diameter of } \\
\text { particles }\end{array}$ & $\begin{array}{c}\text { MK1a } \\
{[\text { [\%] }}\end{array}$ & $\begin{array}{c}\text { MK5 } \\
{[\mathbf{\%}]}\end{array}$ & $\begin{array}{c}\text { T2 } \\
{[\mathbf{\%}]}\end{array}$ & $\begin{array}{c}\text { T3 } \\
{[\text { [\%] }}\end{array}$ & $\begin{array}{c}\text { T5 } \\
{[\mathbf{\%}]}\end{array}$ \\
\hline \hline$<2 \mu \mathrm{m}$ & 3.79 & 2.62 & 7.95 & 9.51 & 3.75 \\
$2-6,3 \mu \mathrm{m}$ & 3.12 & 2.22 & 9.15 & 13.69 & 4.16 \\
$6,3-20 \mu \mathrm{m}$ & 6.89 & 4.35 & 25.10 & 30.20 & 9.49 \\
$20-63 \mu \mathrm{m}$ & 50.70 & 35.41 & 46.50 & 37.10 & 33.90 \\
$63-200 \mu \mathrm{m}$ & 33.90 & 44.40 & 9.50 & 9.30 & 33.50 \\
$200-630 \mu \mathrm{m}$ & 1.60 & 10.10 & 1.80 & 0.20 & 13.40 \\
$630-2000 \mu \mathrm{m}$ & 0.00 & 0.90 & 0.00 & 0.00 & 1.80 \\
\hline
\end{tabular}

The critical locations with higher pollution concentration can be outlined with the help of the simulation dispersion of $\mathrm{PM}_{10}$ pollutants. The most important parameters of the model are the geometry and wind direction. Flow fields including the recirculation bubbles and street canyon vortices were identified by using a computational fluid dynamics (CFD) code (MISKAM). The use and advantages of CFD has been previously described by Goricsán et al. (2011) and Leelössy et al. (2017). The MISKAM code was applied at 6 sites within the study area. The flow patterns and $\mathrm{PM}_{10}$ concentration were modeled at these sites (Fig. 5). 


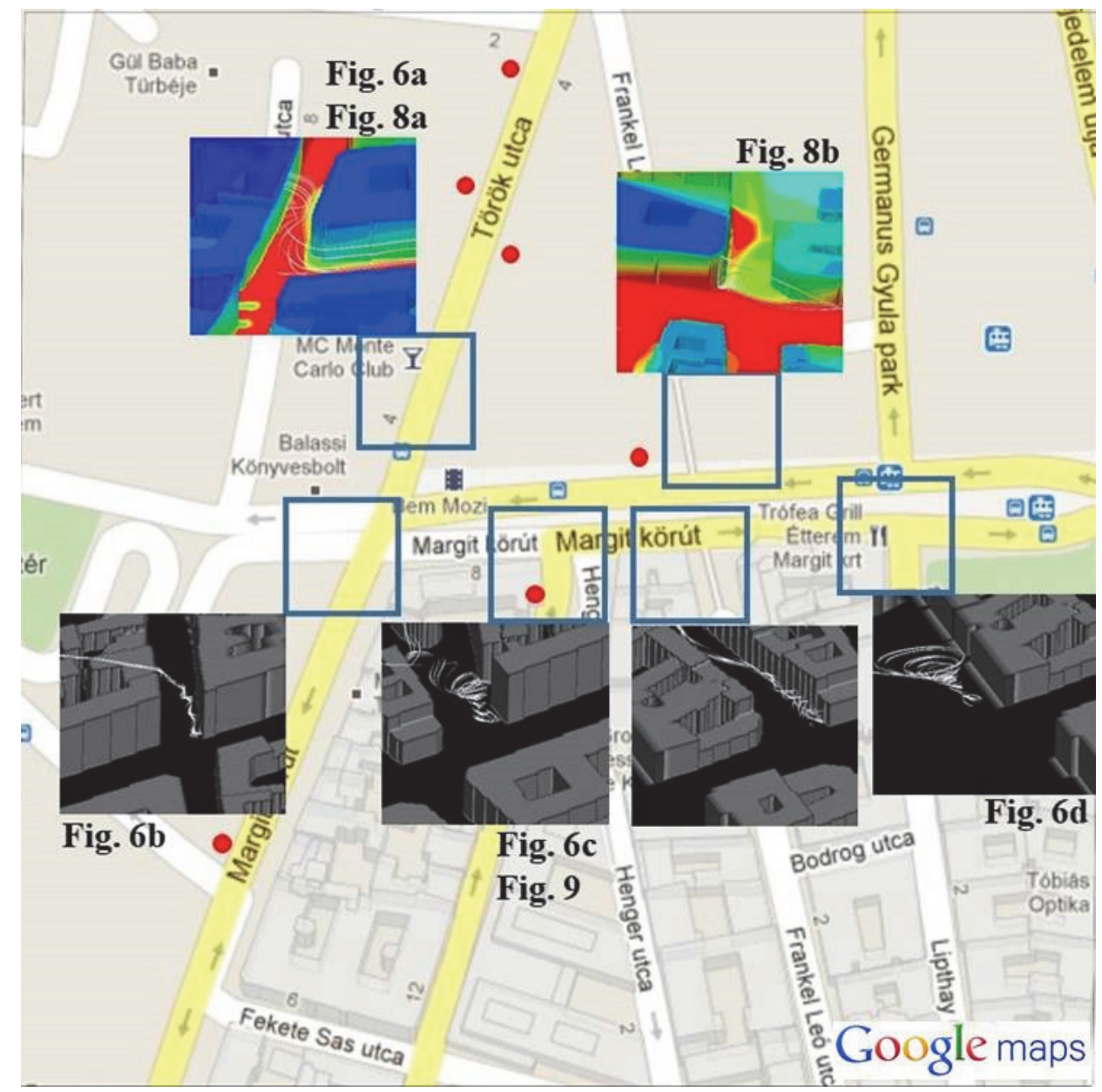

Fig. 5. Study site showing selected locations where flow patterns were detected using computational fluid dynamics (CFD) - MISKAM software.

With the help of CFD, flow patterns were observed. Recirculation in street canyon vortex, corner vortices, as well as outflow and vortex shedding were identified (Fig. 6). Flow patterns typical for urban canopy (Balczó and Lajos, 2015) were also observed in our simulation.

There is mounting evidence that local concentrations of air pollutants are greatly affected by the form of the city. The shape of the urban street canyon can greatly affect heat flow and wind flow patterns. Some possible interactions between wind, pollutants, and pedestrians are given in Fig. 7. 

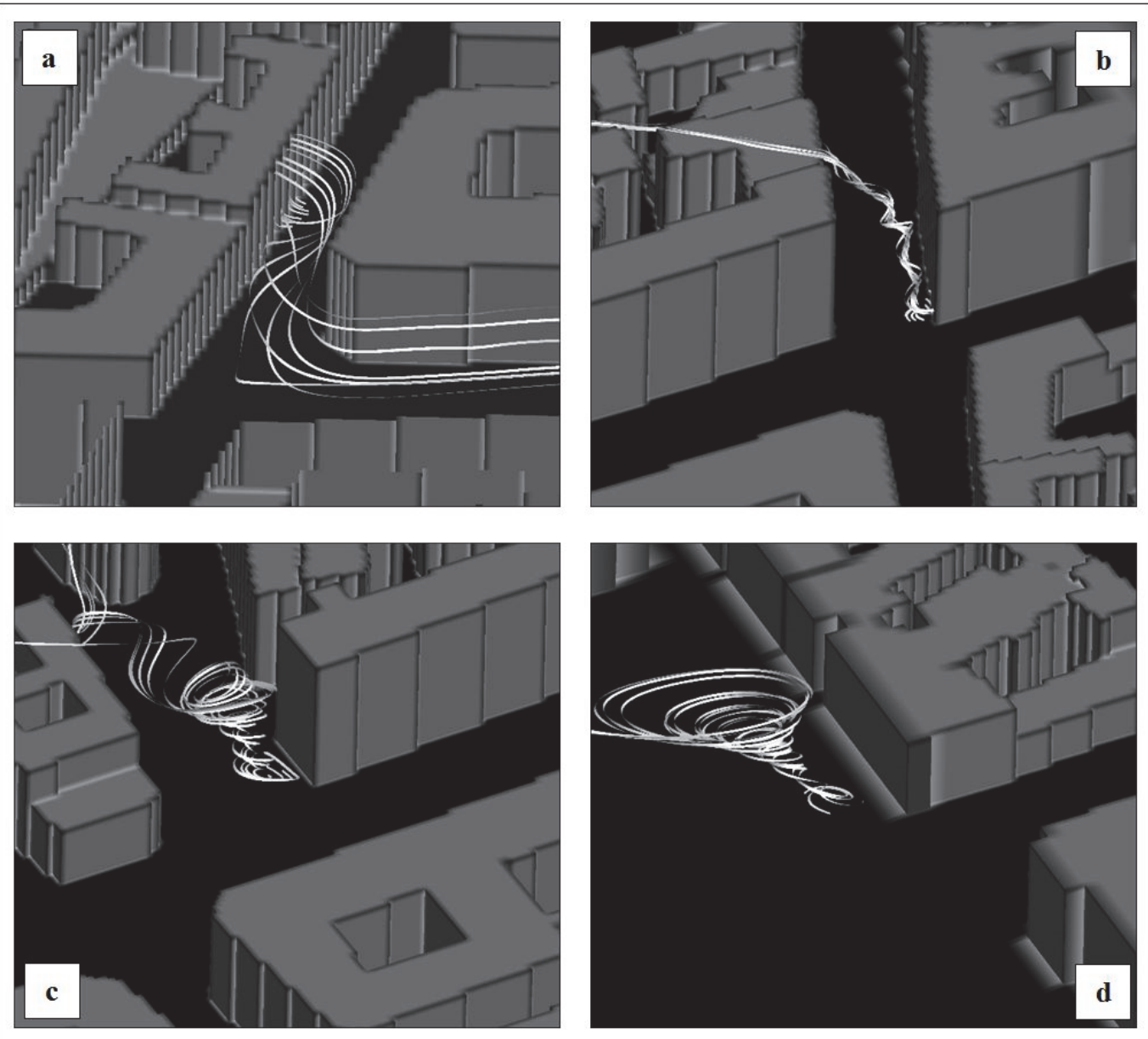

Fig. 6. Flow visualization with 3D streamlines (a. street canyon vortex, b-d. corner vortices and vortices shedding).
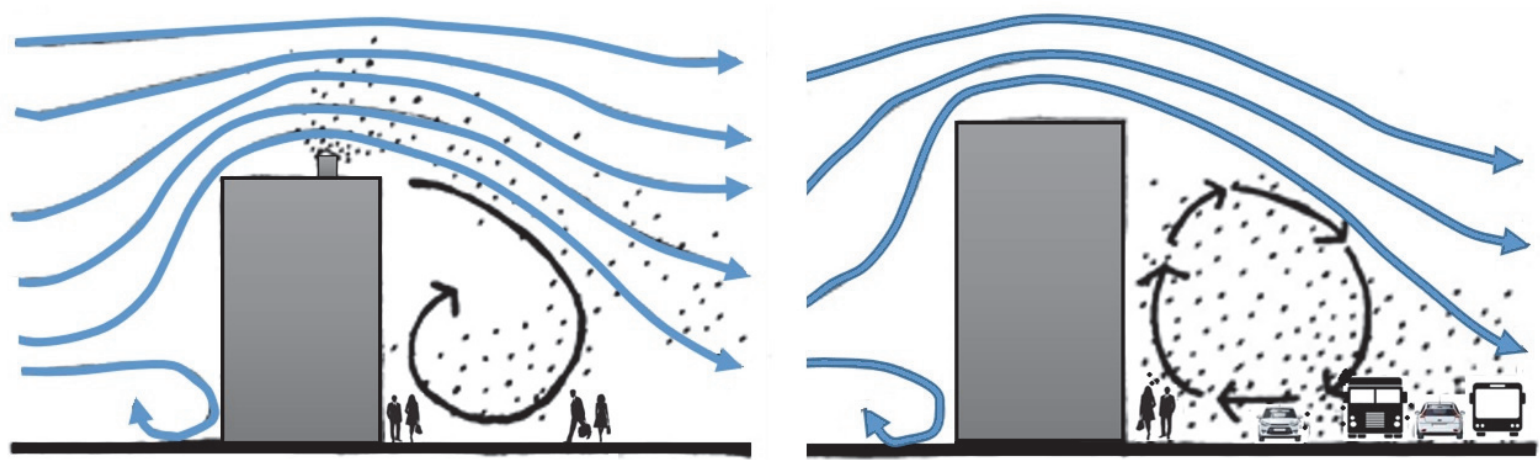

Fig. 7. The flow can sweep pollutants from above buildings or along traffic corridors into pedestrians' path (modified after Spirn (1986)).

Ideally a street canyon is a relatively narrow street with tall, continuous buildings on both sides of the road. Now the term street canyon is used more broadly, and the geometrical details of the street canyon can be used to set up 
different categories (Vardoulakis et al., 2003). In this study there were symmetric (or even) canyons, because the buildings that made the canyon had approximately the same height. When the roof level/background wind direction was perpendicular to the street, a vertically rotating wind flow was created with a centered primary vortex inside street canyons at the Török Street-Margit Boulevard corner (Fig. 8a).
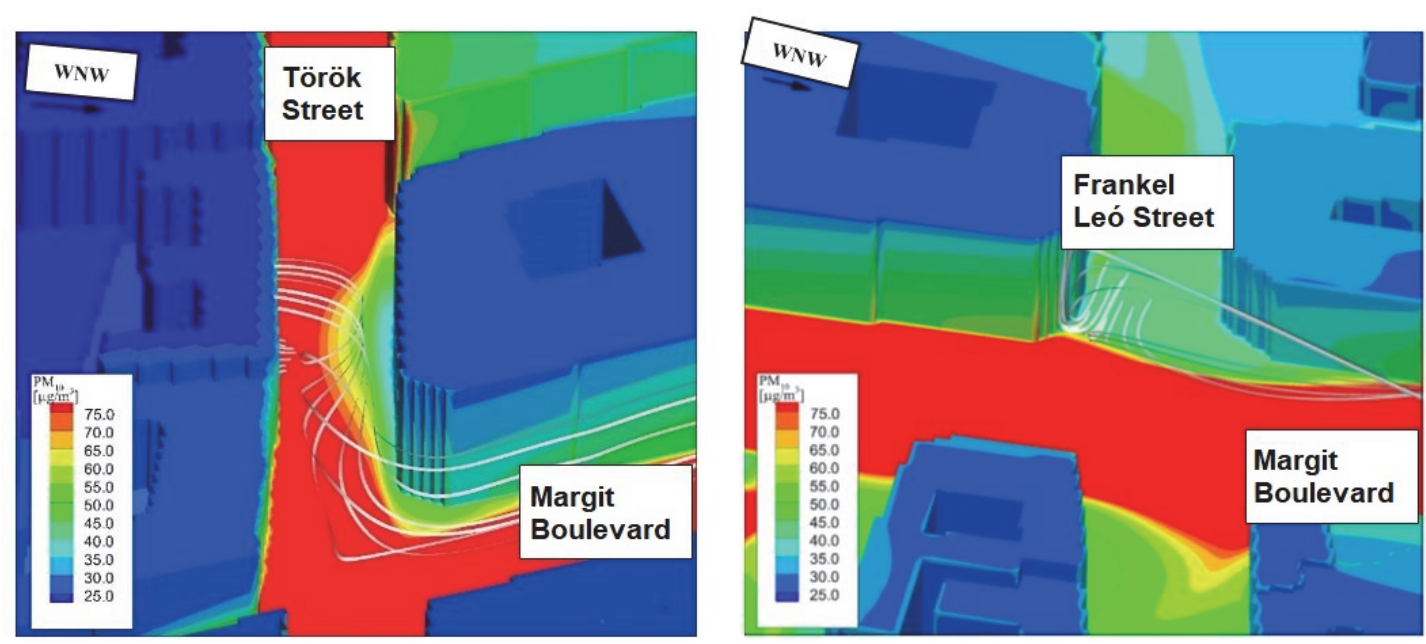

Fig. 8. Street canyon vortex (a) and outflow (b) with $\mathrm{PM}_{10}$ concentration values between $25-75 \mu \mathrm{g} / \mathrm{m}^{3}$.

Outflow was identified at the intersection of Frankel Leó Street and Margit Boulevard (Fig. 6a). There are much lower concentrations at this side of the street (Fig. 8b).

Corner vortex was also identified with CFD modeling at Tölgyfa Street corner (Fig. 6d and (Fig. 9). For such vortices, a vertical axis spiral is formed at the corners of the building, where the pollution is enriched.

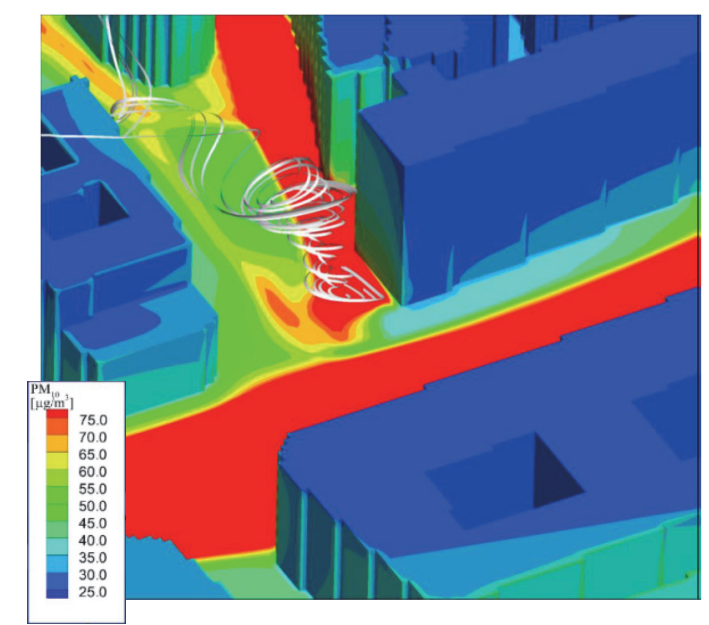

Fig. 9. Corner vortex at the corner of Tölgyfa Street and Margit Boulevard 
We did not analyze the effect of climate change on wind characteristics and changes on flow patterns, but it is known that climate change will significantly influence the wind patterns in Hungary (Péliné et al., 2016), and thus it is very probable, that it will also cause changes in small scale flow patterns such as street vortices.

Additional studies and a large data base with significant amount of dust samples and flow modeling would be required to make a larger scale model that would provide information on the past and present small scale flow patterns of the city center of Budapest.

\section{Conclusion}

The laser particle size analyses of collected dust samples indicate that there are differences in the particle-size distribution of samples. Samples characterized by larger particles often show a bimodal size distribution with particles larger than $200 \mu \mathrm{m}$ in size.

The X-ray diffraction analyses of dust proved that from mineralogical point of view, the major constituents are quartz, dolomite, and calcite. The microscopic study revealed that besides the mineral grains, significant amount of fly ash and soot is also present in the studied samples. The composition of the samples is different, reflects the flow patterns, and also provides information on the geology of the hinterland and the substrate rock (i.e., the ashlar or wall cladding rock). The carbonate content of the dust samples taken from carbonate substrate was always higher than the dust samples taken from other substrate.

With application of MISKAM, a code CFD, taking into account the street geometries, it was possible to identify flow patterns such as recirculation in street canyon vortex, corner vortices, as well as outflow and vortex shedding.

Flow patterns were obtained from CFD. The results of transportation related $\mathrm{PM}_{10}$ emissions were obtained from traffic count and $\mathrm{PM}_{10}$ emission factors. Pollution concentration was calculated by using MISKAM. These results provide important information on the distribution and concentration of $\mathrm{PM}_{10}$. The obtained trends can be used to describe the distribution of larger particles (larger than $\mathrm{PM}_{10}$ ), too.

Street canyon vortex was identified at Török Street. Namely, the dust sample taken from one side of the street (houses with even number, sample T2) has smaller particle sizes, than the samples taken from the other side of the street (houses with odd numbers, sample T5) due to the flow pattern of the street canyon vortex. The central part of the canyon vortex has the lowest velocity, thus the smallest dust particles can also settle.

Additional studies are required to refine and extend the model and to provide an even better correlation between flow patterns, dust deposition, and particle size distribution of dust. With developing a data base, it would be possible to create a model to the entire city center. 
Acknowledgement: The research is supported by the National Research, Development and Innovation Fund (NKFI, ref. no. K 116532). The help of Prof. Dr. Siegfried Siegesmund, Dr. Volker Karius and Dr. Klaus Wemmer for analytical technics are appreciated. The modelling was done at the Department of Fluid Mechanics, Budapest University of Technology and Economics. The help of Anikó Judit Rákai and Károly Czáder are gratefully acknowledged.

\section{References}

Balczó, M. and Lajos, T., 2015: Flow and dispersion phenomena in a simplified urban square. Periodica Polytechnica Civil Engineering 59, 347-360. https://doi.org/10.3311/PPci.7852

Borbély-Kiss, I., Koltay, E., Szabó, Gy., Bozó, L., and Tar, K., 1999: Composition and sources of urban and rural atmospheric aerosol in Eastern Europe. J. Aerosol Sci. 30, 369-391. https://doi.org/10.1016/S0021-8502(98)00051-2

Borsós, T., Řimnáčová, D., Ždimal, V., Weidinger, T., Smolik, J., Wagner, Z., Burkart, J., Steiner, G., Reischl, G., Hitzenberger, R., Schwarz, J., and Salma, I., 2012: Comparison of particulate number concentrations in three Central European capital cities. Sci. Total Environ. 433, 418 426. https://doi.org/10.1016/j.scitotenv.2012.06.052

Bozó, L., 1998: Temporal variation of the atmospheric sulfur budget over Hungary during 1980-1996. Idöjárás 102, 141-147.

Brimblecombe, P. and Grossi C.M., 2009: Millennium-long damage to building materials in London. Sci. Total Environ. 407, 1354-1361. https://doi.org/10.1016/j.scitotenv.2008.09.037

Dockery, W.D., Pope, C.A., Xu, X., Spengler, J.D., Ware, J.H., Fay, M.E., Ferris, B.G., and Speizer, F.E., 1993: An Association between Air Pollution and Mortality in Six U.S. Cities. New England J. Medic. 329, 1753-1759. https://doi.org/10.1056/NEJM199312093292401

Eichhorn, J., 2008: MISKAM Manual for version 5.

Eichhorn, J. and Kniffka, A., 2010: The Numerical Flow Model MISKAM: State of Development and Evaluation of the Basic Version. Meteorol. Zeit. 19, 81-90. https://doi.org/10.1127/0941-2948/2010/0425

Farkas, I. and Weiszburg, T., 2006: Kolozs megyéből (Románia) gyüjtött ülepedő és szálló porok ásványtani vizsgálata. Földtani Közlöny 136, 547-572. (In Hungarian)

Farkas, O., Siegesmund, S., Licha, T., and Török, Á., 2018: Geochemical and mineralogical composition of black weathering crusts on limestones from seven different European countries. Environ. Earth Sci. 77, 211. https://doi.org/10.1007/s12665-018-7384-8

Ferenczi, Z. and Bozó, L., 2017: Effect of the long-range transport on the air quality of greater Budapest area. Int. J. Environ. Poll. 62, 407-416. https://doi.org/10.1504/IJEP.2017.089428

Gieré, R. and Querol, X., 2010: Solid particulate matter in the atmosphere. Elements 6, 215-222. https://doi.org/10.2113/gselements.6.4.215

Goricsán, I., Balczó, M., Czáder, K., Rákai, A., and Tonkó, C., 2011: Simulation of flow in an idealised city using various CFD codes. Int. J. Environ. Poll. 44, 359-367. https://doi.org/10.1504/IJEP.2011.038437

Grobéty, B., Gieré, R., Dietze, V., and Stille, P., 2010: Airborne Particles in the Urban Environment. Elements, 6, 229-234.

Havasi, Á., Bozó, L., and Zlatev, Z., 2001: Model simulation on the transboundary contribution to the atmospheric sulfur concentration and deposition in Hungary. Időjárás 105, 135-144.

Heaney, P.J. and Banfield, J.A., 1993: Structure and chemistry of silica, metal oxides, and phosphates. In: (eds. Guthrie, G.D., Mossman, B.T.,) Reviews in Mineralogy, Vol. 28, Health Effects of Mineral Dusts, Chelsea, MI, Book Crafters, 185-233. https://doi.org/10.1515/9781501509711-008

Hildemann, L.M., Klinedinst, D.B., Klouda, G.A., Currie, L.A., and Cass, G.R., 1994: Sources of Urban Contemporary Carbon Aerosol. Environ. Sci. Technol. 28, 1565-1576. https://doi.org/10.1021/es00058a006

Infras, 2004: Handbook of Emission Factors for Road Transport (HBEFA) version 2.1. 
Jones, R.M., 2003: Particle size analysis by laser diffraction: ISO 13320, standard operating procedures, and Mie theory. Amer. Laborat. 35, 44-47.

Kukkonen, J., Bozó, L., Palmgren, F., and Sokhi, R.S., 2003: Particulate Matter in Urban Air. In (ed.: Moussiopoulos, N.) Air Quality in Cities. Berlin; Heidelberg; New York: Springer-Verlag, 2003. 92-120. https://doi.org/10.1007/978-3-662-05217-4_6

Leelőssy, Á., Molnár, F., Izsák, F., Havasi, Á., Mészáros, R., and Lagzi, I., 2014: Dispersion modelling of air pollutants: a review. Centr. Europ. J. Geosci. 6, 257-278.

Leelössy Á., Lagzi I., and Mészáros R., 2017: Spatial and temporal pattern of pollutants dispersed in the atmosphere from the Budapest Chemical Works industrial site. Idöjárás 121, 101-115.

Lippman, M., Ito, K., Nádas, A., and Burnett, R.T., 2000: Association of particulate matter components with daily mortality and morbidity in urban pollutions. Research Report 95 . Health Effects Institute, Cambridge, USA.

McAlister, J.J., Smith, B.J., and Török, Á., 2006: Element partitioning and potential mobility within surface dusts on buildings in a polluted urban environment, Budapest. Atmos. Environ. 40, 6780-6790. https://doi.org/10.1016/j.atmosenv.2006.05.071

Péliné Németh, Cs., Bartholy, J., Pongrácz, R., and Radics, K., 2016: Analysis of climate change influences on the wind characteristics in Hungary. Idöjárás 120, 53-71.

Pope, C.A., Burnett, R.T., Thun, M.J., Calle, E.E., Krewski, D., Ito, K., and Thurston, G.D., 2002: Lung cancer, cardiopulmonary mortality, and long-term exposure to fine particulate air pollution. JAMA 287, 1132-1141. https://doi.org/10.1001/jama.287.9.1132

Pósfai, M. and Buseck, P.R., 2010: Nature and climate effects of individual tropospheric aerosol particles. Ann. Rev. Earth Planet. Sci. 38, 17-43. https://doi.org/10.1146/annurev.earth.031208.100032

Probáld, F., 2014: The urban climate of Budapest: past, present and future. Hungarian Geograph. Bull. 63, 69-79.

Querol, X., Alastuey, A., Ruiz, C.R., Artiňano, B., Hansson, H.C., Harrison, R.M., Buringh, E., ten Brink, H.M., Lutz, M., Bruckmann, P., Straehl, P., and Schneider, J., 2004: Speciation and origin of $\mathrm{PM}_{10}$ and $\mathrm{PM}_{2,5}$ in selected European cities. Atmos. Environ. 38, 6547-6555. https://doi.org/10.1016/j.atmosenv.2004.08.037

Reichhardt, T., 1995: Weighing the health risk of airborne particulates. Environ. Sci. Technol. 29, 360-364. https://doi.org/10.1021/es00008a744

Rodriguez-Navarro, C. and Sebastian, E., 1996: Role of particulate matter from vehicle exhaust on porous building stones (limestone) sulfation. Sci. Total Environ.187, 79-91. https://doi.org/10.1016/0048-9697(96)05124-8

Salma, I., Maenhaut, W., Weidinger, T., and Pinto, J., 2004a: Temporal variation of secondary organic aerosol in downtown Budapest. J. Aerosol Sci. 35S1, 153-154.

Salma, I., Chi, X., and Maenhaut, W., 2004b: Elemental and organic carbon in urban canyon and background environments in Budapest, Hungary. Atmospheric Environment 38, 27-36.

Salma, I. and Maenhaut, W., 2006: Changes in elemental composition and mass of atmospheric aerosol pollution between 1996 and 2002 in a Central European city. Environ. Pollut. 143, 479-488. https://doi.org/10.1016/j.envpol.2005.11.042

Salma, I., Németh, Z., Weidinger, T., Maenhaut, W., Claeys, M., Molnár, M., Major, I., Ajtai, T., Utry, $N$., and Bozóki, Z., 2017: Source apportionment of carbonaceous chemical species to fossil fuel combustion, biomass burning and biogenic emissions by a coupled radiocarbon-levoglucosan marker method. Atmos. Chemist. Physics 17, 13767-13781. https://doi.org/10.5194/acp-17-13767-2017

Samet, J.M., Dominici, F., Curriero, F.C., Coursac, I., and Zeger, S.L., 2000: Fine particulate air pollution and mortality in 20 U. S. cities, 1987-1994. New England J. Medic. 343, 1742-1749. https://doi.org/10.1056/NEJM200012143432401

Smith, B.J., Török, A., McAlister, J.J., and Megarry, Y., 2003: Observations on the factors influencing stability of building stones following contour scaling: a case study of oolitic limestones from Budapest, Hungary. Build. Environ. 38, 1173-1183.

https://doi.org/10.1016/S0360-1323(03)00076-3 
Spirn, A.W., 1986: Air Quality at the Street-Level: Strategies for Urban Design. Prepared for: Boston Redevelopment Authority.

Temesi, D., Molnár, A., Mészáros, E., and Feczkó, T., 2003: Seasonal and diurnal variation in the size distribution of fine carbonaceous particles over rural Hungary. Atmos. Environ. 37, 139-146. https://doi.org/10.1016/S1352-2310(02)00773-2

Török, A., Licha, T., Simon, K., and Siegesmund, S., 2011: Urban and rural limestone weathering; the contribution of dust to black crust formation. Environ. Earth Sci. 63, 675-693. https://doi.org/10.1007/s12665-010-0737-6

Vardoulakis, S., Fischer, B.E.A., Pericleous, K., and Gonzalez-Flesca, N., 2003: Modelling air quality in street canyons: a review. Atmos. Environ. 37, 155-182. https://doi.org/10.1016/S1352-2310(02)00857-9

Wichmann, H.E., Spix, C., Tuch, T., Woelke, G., Peters, A., Heinrich, J., Kreyling, W.G., and Heyder, J., 2000: Daily mortality and fine and ultrafine particles in Erfurt, Germany. Part I: Role of particle number and particle mass. Health Effects Institute Research Report 98, Cambridge, USA. 